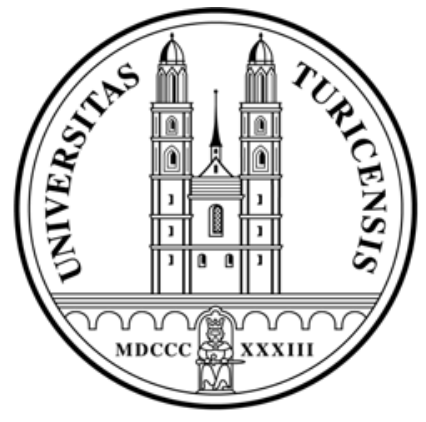

Institute for Empirical Research in Economics

University of Zurich

Working Paper Series

ISSN 1424-0459

Working Paper No. 405

Momentum in stock market returns, risk premia on foreign currencies and international financial integration

Thomas Nitschka

March 2009 


\title{
Momentum in stock market returns, risk premia on foreign currencies and international financial integration
}

\author{
Thomas Nitschka* \\ University of Zurich
}

March 2009

\begin{abstract}
Momentum in developed countries' stock market index returns can be exploited to form portfolios of excess returns on foreign currencies as relatively high past foreign stock market returns signal a foreign currency appreciation. Two risk factors extracted from the stock index momentum based currency portfolio returns explain more than 80 percent of their cross-sectional variation. In contrast to currency risk factors constructed from forward discount sorted currency portfolios, these risk factors are not related to business cycle or liquidity risk. But high currency risk premia are associated with relatively deep financial integration and a high level of risk sharing.

KEYWORDS: CURRENCY RETURNS, FINANCIAL INTEGRATION, MOMENTUM, RISK PREMIA, UIP

JEL CLASSificAtion: F31, F37, G15
\end{abstract}

*Address: University of Zurich, Institute for Empirical Research in Economics, Chair of International Trade and Finance, Zürichbergstrasse 14, CH-8032 Zurich, Switzerland. E-Mail: thomas.nitschka@iew.uzh.ch. An earlier version of this paper (February 2009) circulated under the title "Momentum in stock market returns: Implications for the pricing of risk premia on foreign currencies?" I gratefully acknowledge financial support from the Fond zur Förderung des Akademischen Nachwuchses (FAN) of the University of Zurich sponsored by the Ecosciencia donation. 


\section{Introduction}

Gross cross-border equity holdings as well as capital flows between equity markets have increased strongly during the past two decades (Lane and Milesi-Ferretti (2001,2007), Hau and Rey (2004), Siourounis (2007)). Hau and Rey (2006) provide evidence for a tight link between relative stock market returns, i.e. the return on the foreign stock market in excess of the return on the domestic stock market, and U.S. dollar exchange rate changes in a sample of developed economies. In addition, Siourounis (2007) highlights that equity flows are more important than bond flows in order to predict U.S. dollar exchange rate changes against other major currencies.

These findings form the point of departure for this paper in which I assess empirically if the relation between relative stock market returns and exchange rate changes is strong enough to use the past stock market performance as a signal for exchange rate movements and hence excess returns on foreign currencies. In particular, this paper refers to the observation that past high stock returns tend to be followed by high returns in the short run (momentum) but low returns in the more distant future (long-term reversal). Jagadeesh and Titman (1993) for the U.S. and Rouwenhorst (1998) for a wide cross-section of countries present evidence for momentum at the firm level while DeBondt and Thaler (1985) highlight the long-term reversal effect. Most important for this study Asness, Liew and Stevens (1997) and Bhojraj and Swaminathan (2006) present evidence for momentum in country stock index returns. Richards (1997) shows that long-term reversal is also present in national stock market indices.

Based on these seemingly distinct strands of literature, I take the stance of a U.S. investor to assess if momentum and long-term reversal in national stock market indexes of developed countries can be exploited to form port- 
folios of foreign currency excess returns. This paper is thus closely related to Lustig and Verdelhan (2007) who form currency portfolios based on interest rate differentials to show that consumption-based models explain the cross-sectional variation in excess returns on currency portfolios and hence provide a risk-based explanation for the empirical failure of the uncovered interest rate parity condition (UIP).

The sorting of monthly foreign currency excess returns into five portfolios according to cumulated past relative stock returns for the time period from January 1971 to March 2008 reveals a clearcut pattern: From the perspective of the U.S. investor, past, relatively low foreign stock market returns are associated with currently low foreign currency excess returns and vice versa. This finding holds for various momentum sorts and long-term reversal but only for a sample of developed countries in line with Hau and Rey (2004, 2006). Dissecting the portfolio currency excess returns into the carry, i.e. the interest rate differential, and the spot exchange rate changes reveals that past, high cumulated stock market returns signal a foreign currency appreciation. But they appear to be unrelated to interest rate differentials.

The two first principal components of the stock return momentum sorted currency portfolio returns suffice to explain over 80 percent of the differences in average currency portfolio excess returns. The first principal component is indistinguishable from the arithmetic average of all currency portfolio returns and the second principal component basically mimics the return difference between the winner (highest stock return momentum) and loser (lowest stock return momentum) portfolio. The "winner-minus-loser" factor is significantly priced in the currency portfolio returns.

This finding is reminiscent of the evidence presented by Lustig, Roussanov and Verdelhan (2008) for forward discount/interest rate differential 
sorted currency portfolios. They provide evidence for a two-factor model to explain the cross-section of forward discount sorted currency portfolios. The two factors are the average return on the currency portfolios and the return difference between the high and low forward discount portfolio. The "highminus-low" factor is not only significantly priced but also closely related to and predictable by macroeconomic variables (see also Nitschka (2008) for euro area evidence).

And here is where the similarity between the two-factor model for currency returns based on stock return momentum and interest rate differential sorted currency portfolios breaks down. The "winner-minus-loser" factor does not seem to be connected, i.e. neither predictable nor contemporaneously correlated, to macroeconomic variables that have proved their explanatory power for currency risk premia and carry trades such as consumption growth, industrial production, the term spread etc. and its pricing power is not affected by the inclusion of interest rate differential based pricing factors. Moreover, it does not appear to be associated with measures of crash or funding liquidity risks that are important to explain carry trade returns (Brunnermeier, Nagel and Pedersen (2008)).

These findings leave a bit of a puzzle as Liu and Zhang (2008) demonstrate that covariation with changes in industrial production explains momentum returns in the U.S. stock market to some extent. Furthermore, Asness, Moskowitz and Pedersen (2008) show that measures of funding liquidity are helpful in rationalizing value and momentum across a variety of asset classes albeit this finding only pertains to the common component of the momentum strategies across assets.

Since Lustig et al. (2008) show that their high-minus-low currency risk factor reflects that component of the stochastic discount factor that is com- 
mon across countries, I finally explore if the exposure to global risks explains the characteristics of the high and low stock market momentum based currency portfolios and the stock market winner-minus-loser currency risk factor.

To this end, I first show that the measure of international financial integration proposed by Lane and Milesi-Ferretti $(2001,2007)$ is monotonically increasing from the low to the high stock market momentum currency portfolio. The countries in the stock market winner currency portfolio are more integrated in terms of gross cross-border equity holdings than the loser portfolio countries. Moreover, Brandt, Cochrane and Santa-Clara (2006) advocate an asset price based measure of international risk sharing that, applied to the stock momentum currency portfolios, conveys the notion that the countries in the high momentum currency portfolio also share more risks on financial markets than their low stock momentum counterparts. The countries in the short-term winner stock market currency portfolio seem to be more exposed to global risks than the loser portfolio countries. It also turns out that the stock market loser currency portfolio is negatively correlated with a world stock market return in times of crisis. The opposite reasoning applies to the winner currency portfolio.

Taken together, the main results of this paper suggest that past stock market returns contain information about exchange rate changes of developed economies that is not captured in interest rate differentials. Risk factors constructed from currency portfolios sorted according to stock market momentum do not appear to be related to so far discovered macroeconomic variables that are important to understand the economics of currency excess returns and carry trades. But there is some evidence supporting the view that global risks corresponding with deeper financial integration and 
higher risk sharing through asset markets have the potential to explain the cross-sectional differences in the stock market momentum sorted currency portfolio returns. High asset returns, i.e. currency risk premia and the corresponding stock market returns of the currency portfolios in question, go hand in hand with deeper financial integration and international risk sharing.

The remainder of this paper is organized as follows. Section two provides details of the data, currency portfolio construction and gives descriptive statistics of the currency portfolios in question. Section three presents all of the empirical results and robustness checks. Finally, section four concludes.

\section{Data, currency portfolio formation and descrip- tive statistics}

\subsection{Excess returns on foreign currencies}

The uncovered interest rate parity condition (UIP) suggests that exchange rates should depreciate by the size of the interest rate differential vis-à-vis a base country. Hansen and Hodrick (1980) and Fama (1984) show that UIP is typically violated in the data with the exception of high inflation countries (Bansal and Dahlquist (2000)).

These findings leave the impression of a currency excess return defined as

$$
\phi_{t+1}^{k}=i_{t}^{k}-i_{t}-\Delta s_{t+1}^{k}
$$

where $i_{t}^{k}$ is the country $k$ short-term interest rate, $i_{t}$ its home country counterpart and $\Delta s_{t+1}^{k}$ the change in the spot exchange rate of country $k$ relative to the home currency. An increase in $s$ corresponds to an appreciation of the 
home or depreciation of the foreign currency. This paper considers monthly currency excess returns on 21 developed countries from the perspective of the U.S. investor for the sample period from January 1971 to March 2008. These countries are Australia, Austria, Belgium, Canada, Denmark, Finland, France, Germany, Greece, Ireland, Italy, Japan, Netherlands, New Zealand, Norway, Portugal, Singapore, Spain, Sweden, Switzerland, United Kingdom and the United States. I do not regard the euro countries after the introduction of the euro in January 1999 with the exception of Germany and use 3-month treasury bills or call money market rates as well as the respective U.S. dollar exchange rate from the IMF International Financial Statistics to calculate currency excess returns.

\subsection{Currency portfolios based on past stock market returns}

Lustig and Verdelhan (2007) and Lustig et al. (2008) show that portfolios formed with respect to interest rate differentials or forward discounts reveal a stable pattern in currency excess returns. High interest rate currencies promise higher excess returns than low interest rate currencies. Based on the strong contemporaneous relation between exchange rate changes and relative stock market returns among developed economies (Hau and Rey $(2004,2006))$, this paper assesses if this relation is strong enough to form currency portfolios with respect to past relative stock market returns.

Therefore, I exploit the observation that past high stock market returns signal high stock market returns in the near future, i.e. momentum in stock market indices (Asness et al (1997), Bhojraj and Swaminathan (2006)). The main results presented in section three rely on the formation of currency portfolios according to the 6-6 stock momentum strategy as in Jagadeesh and Titman (1993). Currencies are assigned to a portfolio at time t condi- 
tional on the continuously compounded return of the respective stock market index relative to the U.S. from t-11 to t-6. Hence, currency portfolios in January 1971 are based on the performance of the respective national stock market relative to the U.S. in the period from February 1970 to July 1970. I use country stock indexes in local currency from MSCIBarra to calculate monthly stock market returns and form five portfolios for the sample of developed countries in the period from January 1971 to March 2008 to ensure that portfolios consist of at least two currencies in each month over the whole sample period. These portfolios are rebalanced every month. Portfolio 1 always contains the currencies from countries with lowest past stock returns and portfolio 5 the currencies from countries with highest past stock returns relative to the United States. The portfolio currency excess returns are arithmetic averages of the individual currency excess returns allocated to the portfolios.

Panel A of table 1 provides annualized excess returns, standard deviation and Sharpe ratio of the 6-6 stock market momentum based currency portfolios. Relatively low, past stock returns are associated with a low excess return on foreign currencies and vice versa. Panel B displays the average interest rate differentials and spot exchange rate changes of the currency portfolios. Panel $\mathrm{C}$ gives the cumulated relative stock market returns. It is evident that the pattern we observe in the excess returns on the foreign currency portfolios is not a disguised version of interest rate differential based currency portfolio construction. Relatively high past stock returns signal a foreign currency appreciation six months ahead and vice versa. There is no monotonic increase but rather a U-shape in the interest rate differentials if we move from the first to the fifth portfolio.

This finding even holds when we consider a different stock market mo- 
mentum strategy. Table 2 displays descriptive statistics if currency portfolios are built with respect to the 12-2 stock momentum strategy as examined e.g. in Fama and French (1996). 12-2 momentum strategy means that the currency portfolios in January 1971 are based on the relative cumulated stock market returns for the time period from January to November 1970. The pattern in excess returns on these currency portfolios as well as the decomposition into interest rate differential and spot exchange rate change is consistent with the results presented in table 1. Relatively high foreign stock market returns signal a foreign currency appreciation in the future and hence high excess returns on the foreign currency investment.

Hau and Rey (2006) emphasize that the contemporaneous relation between exchange rate changes and relative stock market returns pertains only to developed economies. Table 3 presents descriptive statistics of five 6-6 stock market momentum sorted currency portfolios for a sample of emerging markets. The sample period runs from January 1989 to March 2008 and comprises the following countries: Chile, China, Colombia, Czech Republic, Egypt, Hungary, India, Indonesia, Israel, Jordan, Korea, Malaysia, Mexico, Morocco, Pakistan, Peru, Philippines, Poland, Russia, Sri Lanka, South Africa, Thailand, Turkey and Venezuela. There is no clearcut pattern in excess returns on these emerging market currency portfolios. A sample of both developed and emerging markets delivers basically the same results (not reported but available upon request). The relation between exchange rate changes and past relative stock market returns seems to apply to the sample of developed countries exclusively.

Finally, I return to the sample of developed countries and assess if longterm reversal in stock market returns (DeBondt and Thaler (1985), Richards (1997)) can be used in order to sort currency portfolios. Long-term reversal 
refers to the observation that past winners, i.e. past high stock returns, tend to be losers (low/negative returns) in the more distant future. Table 4 provides the mean currency excess returns and other statistics if I form currency portfolios according to the 60-13 long-term reversal strategy. Hence, currencies are allocated to portfolios in January 1975 with regard to the respective country's stock market performance from January 1970 to November 1973. The main diagnostics in table 4 are easily summarized. Still high past stock returns are associated with high excess returns on foreign currencies. But the interest rate differentials are almost monotonically increasing with the excess returns as well. Sorting on long-term stock market returns looks similar to the formation of currency portfolios according to the interest rate differentials or forward discounts.

Momentum, however, seems to be special. Excess returns on foreign currency portfolios formed with respect to stock market momentum reveal a clear pattern that is not apparently related to interest rate differentials. The subsequence of this paper is hence focused on these momentum sorted currency portfolios.

\section{Empirical Results}

This section summarizes all of the empricial results of this paper with regard to the 6-6 stock market momentum sorted currency portfolios of developed economies for the time period from January 1971 to March 2008. Section 3.1 follows closely Lustig et al. (2008) in indentifying risk factors that explain differences in the currency portfolio excess returns both in the cross-section as well as over time. Section 3.2. assesses if the risk factors identified in section 3.1 mirror macroeconomic risks and highlights the marked difference between the stock market momentum based risk factors compared to the 
Lustig et al. (2008) risk factors in this respect. Section 3.3. points out that differences in financial integration and hence responsiveness to global risks could be the key to explain the differences across stock market momentum sorted currency portfolio returns. Finally, section 3.4 provides details of some robustness checks.

\subsection{Two-factor model}

Lustig et al. (2008) show that currency portfolios formed according to interest rate differentials or forward discounts inherit all the necessary information to explain their cross-sectional differences. The two first principal components suffice to explain over 80 percent of the variation in forward discount sorted currency excess returns. The first principal component is highly correlated with the average returns on the currency portfolios while the second principal component is closely related to the return difference between the high and low forward discount currency portfolios. Differences in the exposure to this "high-minus-low" risk factor explain most of the cross-sectional variation in currency excess returns.

Table 5 provides the coefficients of the principal components when the five past stock return sorted currency portfolios are regarded. Very similar as for the forward discount/interest rate sorted currency portfolios all of the portfolios load almost equally on the first principal component, interpretable as a level factor, while the second component seems to be a slope factor. Together these two components explain about 90 percent of the portfolios' variance. The first principal component is indistinguishable from the arithmetic average of the five currency portfolio excess returns. The correlation between the two series is 0.99 . The second principal component is strongly correlated (correlation of 0.75 ) with the return difference between 
the winner and the loser portfolios, i.e. the currency portfolios that contain countries with the highest and the lowest past stock market returns vis-à-vis the United States. Hence, as in Lustig et al. (2008), the principal components analysis suggests a two factor model to explain the cross-sectional variation in past stock market performance based currency portfolios. The first risk factor, $R^{F X}$, is the arithmetic average of the currency portfolio returns, the second one, $W M L^{F X}$, is defined as the return difference between the high and low past stock returns currency portfolios.

\subsubsection{Cross-sectional performance}

The cross-sectional empirical results conducted in this paper follow from the basic pricing equation

$$
0=E_{t}\left(m_{t+1} \phi_{t+1}^{j}\right)
$$

with $m_{t+1}=\left(1-\mathbf{b f}_{t+1}\right)$ where $\mathbf{f}_{t+1}$ is the vector of the two pricing factors, $\mathbf{b}$ the vector of corresponding factor loadings and $\phi_{t+1}^{j}$ the excess return on currency portfolio $j$. Lower-case letters denote logarithmic variables in the subsequence.

First, I follow Hansen (1982) and assess which of the two pricing factors helps to price the currency portfolio returns given the presence of the other via GMM. The moment conditions obey

$$
g_{T}(\mathbf{b})=E_{T}\left(m_{t} \mathbf{r}_{t}\right)=E_{T}\left(\mathbf{r}_{t}\right)-E_{T}\left(\mathbf{r}_{t} \mathbf{f}_{t}^{\prime}\right) \mathbf{b}=0
$$

where $\mathbf{r}_{t}$ is the vector of all currency portfolio excess returns, i.e. $\mathbf{r}_{t}=$

$\left[\phi_{t}^{1}, \phi_{t}^{2}, . . \phi_{t}^{5}\right]^{\prime}$, and $E_{T}$ denotes time series averages, i.e. $E_{T}\left(x_{t}\right)=\frac{1}{T} \sum_{t=1}^{T} x_{t}$. Portfolio 1 always contains the currencies from relatively low past stock market performance countries and portfolio 5 the currencies from countries 
with relatively high past stock markt returns accordingly.

In the first stage of the GMM estimation, I use the identity matrix as weighting matrix and in the second stage the optimal weighting matrix with $N+1$ lags, where $N$ is the number of test assets.

Secondly, this paper examines what factors are actually priced by estimating the beta representation of (2) via a Fama-MacBeth (Fama and MacBeth (1973)) regression. The beta representation obeys

$$
E_{t}\left(\phi^{j}\right)=\boldsymbol{\lambda}^{\prime} \boldsymbol{\beta}^{j}
$$

,i.e. the expected excess return on currency portfolio $j$ equals the factor prices, $\lambda$, times the portfolio specific exposure to the factors, $\beta^{j}$.

The first stage of the Fama-MacBeth regression is a time series regression of the currency portfolio returns on the pricing factors. In this case:

$$
\phi_{t}^{j}=\alpha^{j}+\widehat{\beta}_{f x}^{j} r_{t}^{f x}+\widehat{\beta}_{W M L}^{j} w m l_{t}^{F X}+\varepsilon_{t}^{j}
$$

The second stage then amounts to run cross-sectional regressions on the estimated betas at each point in time, i.e.

$$
\phi_{t}^{j}=\widehat{\beta}_{f x}^{j} \lambda_{f x}+\widehat{\beta}_{W M L}^{j} \lambda_{W M L}+v_{t}, \forall t
$$

Table 6 summarizes the cross-sectional results. According to the GMM estimates the winner-minus-loser factor helps to explain the cross-sectional variation in the currency portfolio returns. In addition, the model passes the test of overidentifying restrictions (p-value of J-Test: 0.95). Panel B of table 6 displays that $w m l_{t}^{F X}$ is the decisive risk factor in order to explain the cross- 
sectional differences in the average currency portfolio returns. Its risk price is statistically significant according to the Shanken (1992) corrected t-statistics and is close to its sample mean of 2.33 percentage points per annum. This two-factor model explains about 85 percent of the cross-sectional variation in the currency portfolio returns. Mean squared and mean absolute pricing errors in percentage points per annum are also relatively low with 4 and 13 basis points respectively. Figure 1 provides a visual impression of the fit of the model. The horizontal axis gives the mean returns predicted by the model against the corresponding realized mean returns on the vertical axis. All of the points lie close to the 45 degree line. Figure 2 depicts the mean predicted returns on the horizontal and the respective $\widehat{\beta}_{W M L}^{j}$ on the vertical axis. High returns are associated with relatively high $\widehat{\beta}_{W M L}^{j}$.

\subsubsection{Time series performance}

Table 7 reports the time series performance of the two factor model, i.e. the first stage of the Fama-MacBeth regression. If the model provides a perfect description of the time variation in currency returns, we should observe estimates of the intercepts $\alpha^{j}$ that are zero. Here, the pricing errors $\alpha^{j}$ range from -7 to 29 basis points and all of them are individually not statistically significantly different from zero. In addition, the two factor model explains more than 80 percent of the time series variation in all of the currency portfolio returns.

\subsubsection{Sorting on betas}

The two-factor model seems to provide an adequate description of the crosssectional and time series variation of the stock market momentum based currency portfolios. As a final test of the robustness of the model and the 
importance of the decisive risk facor, $w m l_{t}^{F X}$, I sort currency excess returns according to their betas with respect to $w m l_{t}^{F X}$. I thus run rolling window regressions of country $k$ currency excess return on $w m l_{t}^{F X}$, i.e.

$$
\phi_{t}^{k}=\mu+\beta_{t}^{k, w m l} w m l_{t}^{F X}+\varepsilon_{t}^{k}
$$

for the sample period from January 1971 to March 2008 with a time window of 36 months. Following Lustig et al. (2008) I use only information up to time $t-1$ and rank currencies according to their $\beta_{t}^{k, w m l}$ at each point in time $t$ into five portfolios. Table 8 gives the annualized mean, standard deviation and Sharpe ratio of these beta ranked portfolios. Portfolio 1 contains the currencies with lowest beta with respect to $w m l_{t}^{F X}$ and portfolio 5 the currencies with highest $\beta_{t}^{k, w m l}$. The pattern is clear. Mean returns are monotonically increasing with the WML beta. This finding is robust for various time windows (results not reported but available upon request).

\subsubsection{Subsamples}

Figure 3 shows the average gross cross-border equity holdings to GDP ratio for the 21 developed economies under study. The sample period runs from 1970 to 2004. ${ }^{1}$. As Lane and Milesi-Ferretti (2001, 2007) highlight, we observe a tremendous increase in cross-border equity holdings since the late 1980s leaving the impression of increasing integration of equity markets. Furthermore, Hau and Rey (2004, 2006) argue that the contemporaneous link between exchange rate changes and relative stock market returns is not only a function of financial openness in general but also restricted to the post-1990 period as flows between equity markets have gained considerable importance only since the last two decades.

\footnotetext{
${ }^{1}$ The data is from the IMF website http://www.imf.org/external/pubs/ft/wp/2006/data/wp0669.zip
} 
Taken together, these observations suggest that the empirical success of the two factor model under study should be the outcome of the more recent past. To gauge the plausibility of this argument, I perform the crosssectional pricing exercises reported in table 6 for two subsample periods. Panel A of table 9 provides the results for the time period from January 1971 to December 1989, panel B of table 9 gives the corresponding estimates for the January 1990 to March 2008 sample.

It is evident that the success of the two factor model is driven by the more recent subsample period. The winner-minus-loser factor is only significantly priced in the post 1990s period. This finding is consistent with Hau and Rey $(2004,2006)$ and the observation that equity markets are markedly, internationally intertwined only since the last twenty years.

\subsection{Macroeconomic risks?}

Past cumulated stock market returns relative to the U.S. signal U.S. dollar exchange rate changes six months ahead. Based on this finding, we can identify two risk factors that provide an adequate description of the time series of the currency portfolio returns as well as their cross-sectional differences. These asset pricing outcomes resemble very much what Lustig et al. (2008) highlight for their sample of forward discount or interest rate differential sorted currency portfolios. Furthermore, Lustig et al. (2008) show that the decisive risk factor, the return difference between the high and low forward discount sorted portfolio, reflects macroeconomic risks.

This study exploits momentum in stock market returns. Besides behaviourial and microstructure approaches to explain stock return momentum, Chordia and Shivakumar (2002) suggest time-varying expected returns could play a role in order to rationalize the profitability of momentum strategies. 
More recently, Liu and Zhang (2008) provide evidence for the explanatory power of changes in U.S industrial production for U.S. stock return momentum. Asness et al. (2008) show that the common component in momentum across different asset classes such as stocks, bonds, currencies and commodities can be explained with variables that mirror crash or liquidity risk as suggested by Brunnermeier et al. (2008).

This section assesses the impact of potential macroeconomic risk factors on the currency portfolios built according to past stock market returns. Section 3.2.1 checks if covariation of the currency portfolio returns with macroeconomic risk factors such as consumption growth and industrial production explains their cross-sectional differences. Section 3.2.2 examines if $w m l_{t}^{F X}$ is predictable by variables that mirror business cycle or liquidity risks. For completeness, section 3.2.3. provides details of the performance of a conditional pricing model that uses the potential predictive variables as signals. Section 3.2.4 assesses if risk factors extracted from interest rate differential sorted currency portfolios affect the significance of the stock market momentum based factors.

\subsubsection{Covariation with macroeconomic risk factors}

Liu and Zhang (2008) show that one of the macroeconomic factors identified by Chen et al. (1986), namely changes in industrial production, is priced in returns on momentum sorted U.S. stock portfolios. Hence, this variable could have the potential to explain the currency portfolio returns that are formed with respect to stock market momentum from the U.S. point of view. In addition, I assess if consumption growth could be an explanatory variable as Lustig and Verdelhan (2007) show that exposure to consumption growth explains the cross-section of excess returns on interest rate differential sorted 
currency portfolios. Data on a monthly index of industrial production can be obtained from the Federal Reserve Bank of St Louis, data on monthly non-durable and services consumption as well as the respective CPI and population figures to obtain real, per capita consumption growth is from the Bureau of Economic Analysis. The test assets are still the 6-6 stock market momentum formed currency portfolios.

Table 10 summarizes the results of the cross-sectional pricing exercise. Panel A displays the results when monthly non-durable and services consumption growth is used as pricing factor, panel B reports the corresponding estimates when monthly industrial production is employed. ${ }^{2}$ Neither differences in the exposure to consumption growth nor to changes in industrial production growth seem to suffice in order to explain average excess returns on the past stock return sorted currency portfolios. Covariation with macroeconomic risk factors does not explain the pattern in the currency portfolio returns under study.

\subsubsection{Predictability of "winner-minus-loser" currency risk factor}

Lustig et al. (2008) show that their high-minus-low forward discount currency risk factor is highly predictable by macroeconomic variables. ${ }^{3}$ I employ the three main macroeconomic variables proposed by Chen et al. (1986) to forecast the winner-minus-loser factor. These variables are: the yield spread between a 10-year government bond and the 3-month treasury bill (term

\footnotetext{
${ }^{2}$ As suggested by Chen et al. (1986) I lead changes in monthly industrial production and also considered annual industrial production as pricing factor. None of the results is qualitatively affected by the particular choice of variable. Results are available upon request.

Since monthly consumption growth is likely to be very noisy, I repeated this pricing exercise in quarterly data. None of the results is altered. In addition, Lustig and Verdelhan (2007) show that a specification of the consumption-based CAPM works best taking growth in durable consumption into account. These findings do not pertain in this setting. All of these results are not reported but available upon request.

${ }^{3}$ see also Nitschka (2008) for euro area evidence
} 
spread), the spread between Baa rated long-term corporate bonds and the long-term government bond (default spread) and changes in industrial production $(\Delta i p)$. Furthermore, I assess if variables associated with crash and funding liquidity risk, i.e. changes in the $\mathrm{CBOE}$ option implied volatility index $(\Delta V I X)$ and the yield difference between the 3-month treasury bill and the 3-month eurodollar Libor (TED), predict $w m l_{t}^{F X}$. The latter two variables are motivated by Brunnermeier et al. (2008) who show that these variables predict carry trade premia, i.e. the return difference between high and low interest rate currencies. Moreover, Asness et al. (2008) find that the latter two variables help to explain the common component in momentum strategies across different asset classes. Source for all of the interest rate data is the Federal Reserve Board of Governors. VIX is from finance.yahoo.com.

Table 11 reports the results from regressions of the form

$$
w m l_{t, t+h}^{F X}=\mu+\beta^{h, x} x_{t}+\varepsilon_{t+h}
$$

where $x$ is one of the potential predictive variables. The forecast horizon, $h$, is in months. The sample period runs from January 1971 to March 2008 with the exception of the forecast regression with $\Delta V I X$ for which data is available since February 1990. Newey-West (1987) corrected t-statistics appear below the estimates in parenthesis.

The main result is easily summarized. The decisive risk factor of the two factor model presented in this paper is not predictable by any of the macroeconomic variables under consideration. This finding stands in marked contrast to the evidence provided for forward discount or interest rate differential sorted portfolios. It underscores that the formation of developed countries' currency portfolios according to past relative stock market returns 
is different from interest rate differential based currency portfolio construction. The information about excess returns on foreign currencies inherited in $w m l_{t}^{F X}$ does not seem to be captured by macroeconomic variables that have been identified as being important to understand risk premia on foreign currencies.

\subsubsection{Conditional pricing model}

The cross-sectional results presented so far leave the impression that the pricing equation

$$
0=E_{t}\left(m_{t+1} \phi_{t+1}^{j}\right)
$$

holds if $m_{t+1}=a-b^{r f x} r_{t+1}^{f x}-b^{w m l f x} w m l_{t+1}^{f x}$ conditional on time $t$ information. However, it might be that $w m l_{t+1}^{f x}$ is high in times of high stock market volatility or times in which risk premia, as reflected e.g. in the term spread, are high. To make this point explicit, I consider

$$
0=E\left(x_{t} m_{t+1} \phi_{t+1}^{j}\right)
$$

where $x$ is one of the variables used in section 3.2.2 to forecast $w m l^{f x}$. The stochastic discount factor of this conditional model hence obeys

$$
m_{t+1}=a-b^{r f x} r_{t+1}^{f x}-b^{w m l f x} w m l_{t+1}^{f x}-b^{x \bullet w m l f x} x_{t} w m l_{t+1}^{f x}
$$

Table 12 summarizes the cross-sectional performance of this three factor model with respect to the 6-6 stock market momentum sorted currency portfolios. The sample period runs from January 1971 to March 2008 for all signalling variables except $\Delta V I X$ for which data is available since February 1990. T-statistics in parenthesis are Shanken (1992) corrected. 
There are no cases in which the interaction term of the winner-minusloser factor with the signals, $x$, is statistically significantly priced. Furthermore, the estimates of the two factors $r_{t+1}^{f x}$ and $w m l_{t+1}^{f x}$ are almost unaltered compared to the pricing exercises without taking conditional variables explicitly into account. This conditional pricing exercise hence confirms the impression left by the forecast regressions in the previous subsection.

\subsubsection{Interest rate based currency factors}

The descriptive statistics of the stock market momentum based currency portfolios convey the notion that sorting currencies according to past stock market returns does not coincide with currency portfolio formation with respect to the previous period's interest rate differentials. To alleviate remaining concerns about this issue, I conduct the following exercise. I follow Lustig and Verdelhan (2007) and Lustig et al. (2008) and form five currency portfolios with respect to their interest rate differential vis-à-vis the United States, construct the high-minus-low interest rate differential factor, and include it as an additional pricing factor to the two past stock market performance based factors. The stochastic discount factor is then given by

$$
m_{t+1}=a-b^{r f x} r_{t+1}^{f x}-b^{w m l f x} w m l_{t+1}^{f x}-b^{h m l} h m l_{t+1}^{f x}
$$

I use this discount factor to explain the cross-section of the 6-6 stock market momentum based currency portfolio returns. Table 13 presents the results. The sample period runs from January 1971 to March 2008. T-statistics of the GMM estimates are Newey and West (1987) corrected. Shanken (1992) corrected t-statistics of the risk prices are in parenthesis.

Significance of the winner-minus-loser factor remains untouched, whereas 
the high-minus-low interest rate differential factor neither helps to price the currency excess returns nor is it significantly priced. The past stock return sorted currency portfolio returns are not explained by an interest rate differential based currency risk factor.

\subsection{Financial integration, global risks and currency portfolio returns}

Lustig et al. (2008) show that the formation of currency portfolios allows to extract that component of the stochastic discount factor that is common across countries. Their high-minus-low currency risk factor reflects this common component. This argument should pertain to the winner-minus-loser factor as well since the only difference between the Lustig et al. (2008) risk factors and the ones used in this study lies in the different conditioning variables that are used to form the currency portfolios. Indeed, I find the correlation between the U.S. winner-minus-loser currency risk factor and its German, Japanese and United Kingdom counterpart to vary between 0.75 and 0.95. Hence, different exposures to global risk factors could explain the return differences between the winner and loser currency portfolio. One might argue that the U.S. macroeconomic variables examined earlier in this paper reflect global shocks and thus have already shown that common shocks do not explain the return difference between the stock market winner and loser currency portfolios.

However, section 3.1.4 above shows that the explanatory power of the winner-minus-loser factor is largely driven by the last two decades consistent with the observation that the contemporaneous relation between exchange rates and relative stock market returns seems to depend on the extent of financial integration (Hau and Rey (2006)). Hence, differences in the degree 
of financial integration since the 1990s and thus differences in the exposure to global risks could be responsible for the cross-sectional variation of the stock market momentum sorted currency portfolios.

I use the measure of financial integration proposed by Lane and MilesiFerretti $(2001,2007)$, i.e. the average gross cross-border equity holdings to GDP ratio, to assess if there are differences in financial integration across the countries assigned to the different currency portfolios. Since the data, freely available on the IMF website, is annual I assume that the annual values pertain to all months in a particular year and calculate the Lane and Milesi-Ferretti financial integration measure for all of the developed countries under study. Panel A of table 14 presents the average cross-border equity holdings to GDP ratio of the countries in the five currency portfolios for the sample period from January 1990 to December 2004. A high value implies a high extent of market integration. Clearly, financial integration increases from the loser to the winner portfolio. The winner portfolio seems to contain countries that are more integrated in terms of gross cross-border equity holdings than the countries in the other portfolios especially the loser currency portfolio.

Sørensen et al. (2007) and Fratzscher and Imbs (2007) show that financial integration improves international risk sharing. The results presented in panel B of table 14 for the sample period from January 1990 to March 2008 confirm this finding for the countries in the currency portfolios under study using the measure of international risk sharing proposed by Brandt et al. (2006). Brandt et al. (2006) exploit that exchange rate changes should mirror differences in home and foreign marginal utility growth, i.e.

$$
\Delta s_{t+1}=m_{t+1}^{f}-m_{t+1}^{d}
$$


with $\Delta s_{t+1}$ the change in the log nominal exchange rate and $m_{t+1}^{f}$ as well as $m_{t+1}^{d}$ the log nominal stochastic discount factors of the foreign and home country respectively. This relation allows to compute the following index of risk sharing

$$
1-\frac{\sigma^{2}\left(m_{t+1}^{f}-m_{t+1}^{d}\right)}{\sigma^{2}\left(m_{t+1}^{f}\right)+\sigma^{2}\left(m_{t+1}^{d}\right)}=1-\frac{\sigma^{2}\left(\Delta s_{t+1}\right)}{\sigma^{2}\left(m_{t+1}^{f}\right)+\sigma^{2}\left(m_{t+1}^{d}\right)}
$$

where $m_{t+1}^{d}$ and $m_{t+1}^{f}$ are based on asset prices and thus obey

$$
m_{t+1}^{d}=\left[\begin{array}{c}
\theta^{d}-r^{d} \\
\theta^{e}+r^{f}-r^{d} \\
\theta^{f}-r^{f}+\Sigma^{e f}
\end{array}\right]
$$

and

$$
m_{t+1}^{f}=\left[\begin{array}{c}
\theta^{d}-r^{d}-\Sigma^{e d} \\
\theta^{e}+r^{f}-r^{d}-\Sigma^{e e} \\
\theta^{f}-r^{f}
\end{array}\right]
$$

respectively with $\theta^{d}$ the domestic stock return, $r^{d}$ the domestic interest rate, the exchange rate $e$ and $\theta^{f}, r^{f}$ the foreign country counterparts and $\Sigma$ the covariance matrix of innovations in exchange rates, domestic and foreign stock markt returns. Brandt et al. (2006) highlight that this measure indicates a much higher level of international risk sharing than consumption-based ones as e.g. presented in Sørensen and Yosha (1998). When we compare the risk sharing indexes of the (synthetic) average country of the currency portfolios, it is evident that not only financial integration but also risk sharing vis-à-vis the United States increases monotonically from the low to the high stock market momentum currency portfolios. Both of these findings are interesting as these suggest the following: Deep financial integration in 
terms of cross-border equity holdings corresponds to more risk sharing on international financial markets and relatively high asset returns. This finding suggests that financial integration and lots of risk sharing via international asset markets are also associated with a relatively high exposure to global risks in order to rationalize the high currency as well as the respective stock returns of the currency portfolios under study. Given that there are differences in the responsiveness to global shocks, a related question is if the countries in the winner portfolio are exposed to more global risks on average or in certain periods of time. While a fully satisfying answer is beyond the scope of this paper, figure 4 depicts the rolling 12-month correlation of the currency excess returns of the winner and loser currency portfolio with respect to the MSCIBarra world stock market return as a proxy for global risks. The time period is again from January 1990 to March 2008. The loser portfolio's currency return is negatively correlated with the world stock market in times of crisis which would hence explain its low excess returns. The opposite reasoning applies to the winner portfolio. In tranquil times there is not much of a difference in the world stock market correlation of the winner and loser currency portfolio returns. Lustig et al. (2008) report a similar finding with respect to the correlation with the U.S. stock market for their high-minus-low forward discount currency factor.

\subsection{Robustness checks}

The main results presented in this paper rely on currency portfolios built with respect to cumulated stock market returns vis-à-vis the United States six months prior to the date of the realized currency returns (6-6 momentum in national stock index returns). For completeness table 15 presents the corresponding cross-sectional pricing results if the two factors, $r^{f x}$ and 
$w m l^{f x}$ are calculated from currency portfolios formed according to past stock market returns 2 months prior to the portfolio formation period (12-2 momentum). It thus complements table 2 which presents the descriptive statistics of these portfolios. The results are very similar to the 6-6 stock market momentum sorted currency portfolios. The winner-minus-loser factor is significantly priced in the average excess returns on these currency portfolios.

Table 16 provides estimates from the attempt to price currency portfolio returns formed according to 6-6 stock market momentum for a sample of emerging markets with the respective two factors. Consistent with the descriptive statistics of table 3 , the two-factor model works poorly and highlights that the link between past stock market performance and excess returns on foreign currency returns is limited to a sample of developed economies.

Even at longer time horizons past stock market returns of developed countries seem to be informative about exchange rate changes. This is the message conveyed by table 4 which displays the descriptive statistics based on long-term reversal in stock market returns. Table 17 presents results for the corresponding two factor model which leave the same impression as the cross-sectional pricing exercises based on momentum formed currency portfolios. However, as already noted, the characteristics of the long-term reversal sorted currency portfolios suggest that this kind of sorting seems to be closely related to the formation of currency portfolios based on interest rate differentials. Indeed, the winner-minus-loser factor constructed from these currency portfolio returns exhibits a modest degree of predictability by industrial production growth (results not reported in tables but available upon request). Lustig et al. (2008) provide similar evidence for their 
high-minus-low forward discount factor. Hence, currency portfolio formation according to long-term reversal in stock market returns seems to be directly related to business cycle risks.

Table 18 provides descriptive statistics for currency portfolios sorted according to the demeaned 6-6 stock market momentum returns. This exercise is motivated by Bulkley and Nawosah (2007) who show that momentum is not present in demeaned firm-level stock returns. They employ the mean of the stock returns as a measure of unconditional expected returns and argue that taking account of the cross-sectional dispersion in these unconditional expected returns largely explains the presence of momentum in firm-level stock returns. Tables 18 and 19 show that the findings of Bulkley and Nawosah (2007) seem to pertain also to stock index returns and hence to the currency portfolios based on their past performance. However, the main results of this paper remain qualitatively unaffected. Past high foreign stock market returns signal a foreign currency appreciation and hence create a stable pattern in currency excess returns. Risk factors constructed from these currency portfolio returns explain their cross-sectional differences.

Table 20 presents mean average currency excess returns for the 6-6 momentum sorted currency portfolios from the perspective of a German, Japanese and UK investor. Past high foreign stock market returns are associated with relatively high currency excess returns. Table 21 displays the results from cross-sectional pricing exercises of the two-factor model under study. The estimates complement the U.S. evidence.

\section{Concluding remarks}

Past stock market returns signal high stock market returns in the near future. Foreign relative to home stock market returns are closely related to the 
respective contemporaneous exchange rate changes. Against the backdrop of these two observations, this paper provides evidence that excess returns on currency portfolios formed according to momentum on stock markets reveal a clearcut pattern: High foreign stock market returns relative to the U.S. signal a high excess return on foreign currencies and vice versa. High past stock market returns are associated with a foreign currency appreciation in the future. This observation is not driven by interest rate differentials and holds for a sample of developed economies for the time period from January 1971 to March 2008 but seems to be driven by the post 1990s period.

The currency portfolios' exposure to the return difference between the winner (highest past stock market returns) and loser (lowest past stock market returns) portfolio explains most of the time series and cross-sectional variation of the stock market momentum based currency portfolios. This winner-minus-loser factor seems be unrelated to fundamental, macroeconomic explanatory variables of currency risk premia proposed so far. This latter finding leaves open the possibility that the winner-minus-loser currency risk factor could be related to risks associated with peso problems that Burnside et al. (2008) regard as the candidate explanation for the profitability of the carry trade strategy in a sample of developed countries that is similar to the sample under consideration in this paper. However, return differences between the stock market momentum sorted currency portfolios are associated with three observations: The countries in the winner currency portfolio are on average more integrated in terms of gross cross-border equity holdings and share more risks on financial markets than the average country in the loser portfolio. In addition, the loser currency returns are negatively correlated with the world stock market return, a proxy for global risks, in times of crisis. The opposite reasoning applies to the stock mar- 
ket winner currency portfolio. Taken together, these observations suggest that differences in the sensitivity to global risks could explain the pattern in excess returns on stock market momentum based currency portfolios.

\section{References}

[1] Asness, C.S., Liew, J.M. and R. L. Stevens (1997), "Parallels Between the Cross-Sectional Predictability of Stock and Country Returns", Journal of Portfolio Management 23, 79-87.

[2] Asness, C.S., Moskowitz, T.J. and L.H. Pedersen (2008), "Value and Momentum Everywhere", working paper

[3] Bansal, R. and Dahlquist, M. (2000), "The Forward Premium Puzzle: Different Tales from Developed and Emerging Markets", Journal of International Economics 51(1), 115-144.

[4] Brandt, M.W., Cochrane, J.H. and P. Santa-Clara (2006), "International risk sharing is better than you think, or exchange rates are too smooth", Journal of Monetary Economics 53, 671-698.

[5] Brunnermeier, M., Nagel S. and L.H. Pedersen (2008), "Carry Trades and Currency Crashes", NBER Macroeconomics Annual forthcoming

[6] Bulkley, G. and V. Nawosah (2007), "Can the Cross-Sectional Variation in Expected Stock Returns Explain Momentum?", Journal of Financial and Quantitative Analysis forthcoming

[7] Burnside, C., Kleshcheski, I., Eichenbaum, M. and S. Rebelo (2008), " Can Peso Problems Explain the Returns to the Carry Trade?", working paper

[8] Bhojraj, S. and B. Swaminathan (2006), "Macromomentum: Returns Predictability in International Equity Indices", Journal of Business 79, 429-451.

[9] Chen, N., Roll, R. and S.A. Ross (1986), "Economic Forces and the Stock Market", Journal of Business 59, 383-483. 
[10] Chordia, T. and L. Shivakumar (2002), "Momentum, Business Cycle, and Time-Varying Expected Returns", Journal of Finance 57, 9861019 .

[11] DeBondt, W.F.M. and R.H. Thaler (1985), "Does the stock market overreact?", Journal of Finance 40, 793-805.

[12] Fama, E.F. (1984), "Forward and Spot Exchange Rates", Journal of Monetary Economics 14, 319-338.

[13] Fama, E.F. and K.R. French (1996), "Multifactor Explanations of Asset Pricing Anomalies", Journal of Finance 53, 55-84.

[14] Fama, E. F. and J.D. MacBeth (1973), "Risk, Return and Equilibrium: Empirical Tests", Journal of Political Economy, 81, 607-631.

[15] Fratzscher, M. and J. Imbs (2007), "Risk Sharing, Finance and Institutions in International Portfolios", ECB working paper 826, Journal of Financial Economics forthcoming

[16] Hansen, L.P. (1982), "Large Sample Properties of Generalized Methods of Moments Estimators", Econometrica 50, 1029-1054.

[17] Hansen, L.P. and R.J. Hodrick (1980), "Forward Exchange Rates as Optimal Predictors of Future Spot Rates: An Econometric Analysis", Journal of Political Economy 88, 829-853.

[18] Hau, H. and H. Rey (2004), "Can Portfolio Rebalancing Explain The Dynamics Of Equity Returns And Exchange Rates?", American Economic Review PEYP, 94, 126-133.

[19] Hau, H. and H. Rey (2006), "Exchange Rates, Equity Prices and Capital Flows", Review of Financial Studies, 19, 273-317.

[20] Jagadeesh, N. and S. Titman (1993), "Returns to buying winners and selling losers: Implications for stock market efficiency" Journal of Finance 48, 65-91.

[21] Lane, P. and G.M. Milesi-Ferretti (2001), "The External Wealth of Nations: Measures of Foreign Assets and Liabilities for Industrial and Developing Nations", Journal of International Economics 55, 263-294. 
[22] Lane, P. and G.M. Milesi-Ferretti (2007), "The external wealth of nations mark II: Revised and extend estimates of foreign assets and liabilities, 1970-2004", Journal of International Economics 73, 223-250.

[23] Liu, L.X. and L. Zhang (2008), "Momentum Profits, Factor Pricing, and Macroeconomic Risk", Review of Financial Studies 21, 2417-2448.

[24] Lustig, H., Roussanov, N. and A. Verdelhan (2008), "Common Risk Factors in Currency Markets", working paper

[25] Lustig, H. and A. Verdelhan (2007), "The Cross-section of Foreign Currency Risk Premia and U.S. Consumption Growth Risk", American Economic Review 97, 89-117.

[26] Newey W.K. and K.W. West (1987), "A simple, positive semidefinite, heteroskedasticity and autocorrelation consistent covariance matrix", Econometrica 55, 703-708.

[27] Nitschka, T. (2008), "Idiosyncratic Consumption Risk and Predictability of the Carry Trade Premium: Euro Area Evidence", IEW working paper 387, University of Zurich

[28] Richards, A.J. (1997), "Winner-Loser Reversals in National Stock Market Indices: Can They be Explained?", Journal of Finance 52, 21292144 .

[29] Rouwenhorst, G.K. (1998), "International momentum strategies", Journal of Finance 53, 267-283.

[30] Siourounis, G. (2007), "Capital Flows and Exchange Rates: An Empirical Analysis", working paper

[31] Shanken, J. (1992), "On the Estimation of Beta-Pricing Models", Review of Financial Studies, 5, 1-33.

[32] Sørensen, B., Yosha, O., Wu, Y.-T. and Zu, Y. (2007), "Home Bias and International Risk Sharing: Twin Puzzles Separated at Birth", Journal of International Money and Finance, 26, 587-625.

[33] Sørensen, B. and O. Yosha (1998), "International Risk Sharing and European Monetary Unification", Journal of International Economics 45, 211-238. 


\section{Tables}

Table 1: Descriptive Statistics (6-6 momentum)

\begin{tabular}{|c|c|c|c|c|c|}
\hline \multicolumn{6}{|c|}{ Panel A: Excess returns on currency portfolios } \\
\hline & $\mathrm{P} 1$ & $\mathrm{P} 2$ & P3 & $\mathrm{P} 4$ & $\mathrm{P} 5$ \\
\hline excess return & 0.77 & 1.65 & 2.07 & 2.35 & 3.10 \\
\hline standard deviation & 8.66 & 9.03 & 8.82 & 8.80 & 8.94 \\
\hline Sharpe Ratio & 0.09 & 0.18 & 0.23 & 0.27 & 0.35 \\
\hline \multicolumn{6}{|c|}{ Panel B: Characteristics } \\
\hline interest rate differential & 1.10 & 0.84 & 0.70 & 0.80 & 0.88 \\
\hline spot exchange rate & 0.33 & -0.81 & -1.38 & -1.56 & -2.23 \\
\hline \multicolumn{6}{|c|}{ Panel C: Relative stock returns } \\
\hline mean return & -25.77 & -8.01 & 2.32 & 13.06 & 33.46 \\
\hline
\end{tabular}

Notes: Table 1 provides annualized excess returns, the corresponding standard deviation and Sharpe ratio (panel A) as well as mean interest rate differentials visà-vis the U.S. and the respective mean spot exchange rate changes (panel B) in percentage points p.a. of currency portfolios sorted according to countries' momentum in stock markets. The momentum strategy relies on the six month continuously compounded return with a holding period of six months following Jagadesh and Titman (1993). The relative compounded returns denominated in local currency and percentage points p.a. are given in panel C. The sample period runs from January 1971 to March 2008 and comprises 21 developed economies. Portfolio P1 contains the currencies from the lowest momentum stock return countries, P5 contains the high momentum currencies. 
Table 2: Descriptive Statistics (12-2 momentum)

\begin{tabular}{cccccc}
\hline \hline \multicolumn{6}{c}{ Panel A: Excess returns on currency portfolios } \\
\hline & P1 & P2 & P3 & P4 & P5 \\
excess return & 0.11 & 1.63 & 2.10 & 2.11 & 2.43 \\
& & & & & \\
standard deviation & 9.29 & 9.03 & 8.99 & 8.64 & 8.90 \\
& & & & & \\
Sharpe Ratio & 0.01 & 0.18 & 0.23 & 0.24 & 0.27 \\
\hline \multicolumn{6}{c}{ Panel B: Characteristics } \\
interest rate differential & 1.13 & 0.83 & 0.74 & 0.71 & 1.11 \\
spot exchange rate & 1.02 & -0.80 & -1.36 & -1.40 & -1.32
\end{tabular}

Notes: Table 2 provides annualized excess returns, the corresponding standard deviation and Sharpe ratio (panel A) as well as mean interest rate differentials visà-vis the U.S. and the respective mean spot exchange rate changes (panel B) in percentage points p.a. of currency portfolios sorted according to countries' momentum in stock markets. The momentum strategy relies on the ten month continuously compounded return with a holding period of two months as described in Fama and French (1996). The sample period runs from January 1971 to March 2008 and comprises 21 developed economies. Portfolio P1 contains the currencies from the lowest momentum stock return countries, P5 contains the high momentum currencies. 
Table 3: 6-6 momentum (emerging markets)

\begin{tabular}{cccccc}
\hline \hline & P1 & P2 & P3 & P4 & P5 \\
excess return & 1.96 & 1.72 & 2.36 & 5.48 & 3.44 \\
& & & & & \\
standard deviation & 6.64 & 6.78 & 6.42 & 5.86 & 7.91 \\
& & & & & \\
Sharpe Ratio & 0.29 & 0.25 & 0.37 & 0.94 & 0.43 \\
\hline
\end{tabular}

Notes: Table 3 provides annualized excess returns, the corresponding standard deviation and Sharpe ratio as well as mean interest rate differentials vis-à-vis the U.S. and the respective mean spot exchange rate changes in percentage points p.a. of currency portfolios sorted according to countries' momentum in stock markets. The momentum strategy relies on the six month continuously compounded return with a holding period of six months following Jagadesh and Titman (1993).The sample period runs from January 1989 to March 2008 and comprises 24 emerging economies. Portfolio P1 contains the currencies from the lowest momentum stock return countries, P5 contains the high momentum currencies. 
Table 4: Descriptive Statistics (long-term reversal)

\begin{tabular}{cccccc}
\hline \hline \multicolumn{6}{c}{ Panel A: Excess returns on currency portfolios } \\
\hline & P1 & P2 & P3 & P4 & P5 \\
excess return & -0.36 & 0.38 & 1.86 & 1.26 & 3.99 \\
& & & & & \\
standard deviation & 8.33 & 9.12 & 9.16 & 9.09 & 9.20 \\
& & & & & \\
Sharpe Ratio & -0.04 & 0.04 & 0.20 & 0.14 & 0.43 \\
\hline \multicolumn{6}{c}{ Panel B: Characteristics } \\
interest rate differential & 0.23 & 0.82 & 0.95 & 0.80 & 1.64 \\
& & & & & \\
spot exchange rate & 0.60 & 0.44 & -0.91 & -0.46 & -2.35
\end{tabular}

Notes: Table 4 provides annualized excess returns, the corresponding standard deviation and Sharpe ratio(panel A) as well as mean interest rate differentials visà-vis the U.S. and the respective mean spot exchange rate changes (panel B) in percentage points p.a. of currency portfolios sorted according to countries' longterm reversal in stock markets. The long-term reversal strategy relies on the 47 month continuously compounded return with a holding period of thirteen months as described in DeBondt and Thaler (1985) and Richards (1997). The sample period runs from January 1975 to March 2008 and comprises 21 developed economies. Portfolio P1 contains the currencies from the lowest past long-term stock return countries, P5 contains the high long-term stock return currencies. 
Table 5: Principal Components

\begin{tabular}{cccccc}
\hline \hline & \multicolumn{5}{c}{ principal component } \\
portfolio & 1 & 2 & 3 & 4 & 5 \\
\hline 1 & -0.44 & 0.62 & -0.16 & 0.18 & 0.73 \\
2 & -0.46 & 0.46 & 0.23 & -0.09 & -0.59 \\
3 & -0.45 & -0.28 & -0.55 & -0.64 & -0.06 \\
4 & -0.45 & -0.37 & -0.27 & 0.72 & -0.26 \\
5 & -0.45 & -0.43 & 0.74 & -0.16 & 0.21 \\
& & & & & \\
\% Variance & 83.04 & 5.81 & 4.07 & 3.57 & 3.50
\end{tabular}

Notes: Table 5 presents the principal component coefficients of the five stock return momentum sorted currency portfolio returns for the sample period from January 1971 to March 2008. The last row shows how much of the total variance is explained by each component. 
Table 6: Cross-sectional performance of two-factor model

\begin{tabular}{|c|c|c|c|c|}
\hline \multicolumn{5}{|c|}{ Panel A: GMM (factor loadings) } \\
\hline$b^{f x}$ & $b^{W M L}$ & J-test (p-value) & & \\
\hline $\begin{array}{c}2.77 \\
(1.23)\end{array}$ & $\begin{array}{l}6.70 \\
(2.29)\end{array}$ & 0.95 & & \\
\hline \multicolumn{5}{|c|}{ Panel B: Fama-MacBeth risk prices } \\
\hline$\lambda^{f x}$ & $\lambda^{W M L}$ & $R^{2}$ & mspe & mape \\
\hline $\begin{array}{c}1.99 \\
(1.50)\end{array}$ & $\begin{array}{c}2.38 \\
(2.50)\end{array}$ & 0.85 & 0.03 & 0.14 \\
\hline
\end{tabular}

Notes: Table 6 reports the performance of the two-factor model in crosssectional asset pricing tests with regard to the 6-6 stock market momentum sorted currency portfolios described in table 1. Panel A provides the two stage GMM estimates of the factor loadings. I use the identity matrix as weighting matrix in the first stage and the optimal weighting matrix in the second stage. Newey-West (1987) corrected t-statistics appear below the estimates in parenthesis. The p-value of the test of overidentifying restrictions is depicted in the third column. Panel B presents estimates of risk prices, $R^{2}$, mean squared pricing error (mspe) and mean absolute pricing errors (mape) in percentage points p.a. T-statistics in parenthesis are Shanken (1992) corrected. The sample period runs from January 1971 to March 2008 and comprises 21 developed economies 
Table 7: Time series performance of two-factor model

\begin{tabular}{ccccc}
\hline \hline portfolio & $\alpha^{j}$ & $\beta_{f x}^{j}$ & $\beta_{W M L}^{j}$ & $R^{2}$ \\
\hline$P 1$ & -0.07 & 0.99 & -0.48 & 0.94 \\
& $(-0.21)$ & $(52.69)$ & $(-17.89)$ & \\
$P 2$ & -0.22 & 1.02 & -0.07 & 0.84 \\
& $(-0.35)$ & $(36.78)$ & $(-2.20)$ & \\
$P 3$ & 0.07 & 1.00 & 0.01 & 0.84 \\
& $(0.12)$ & $(33.58)$ & $(0.19)$ & \\
$P 4$ & 0.29 & 1.00 & 0.03 & 0.85 \\
& $(0.49)$ & $(35.58)$ & $(1.90)$ & 0.95 \\
& -0.07 & 0.99 & 0.52 &
\end{tabular}

Notes: Table 7 displays estimates from the first-stage of the Fama-MacBeth regression of the two-factor model when confronted with the 6-6 stock market momentum sorted currency portfolios described in table 1 . The regression takes the following form:

$$
\phi_{t}^{j}=\alpha^{j}+\widehat{\beta}_{f x}^{j} r_{t}^{f x}+\widehat{\beta}_{W M L}^{j} w m l_{t}^{F X}+\varepsilon_{t}^{j}
$$

The estimates of the pricing errors $\alpha^{j}$ are in percentage points p.a., the corresponding Newey-West (1987) corrected t-statistics appear in parenthesis. $R^{2}$ is adjusted for the number of regressors. The sample period runs from January 1971 to March 2008 and comprises 21 developed economies 
Table 8: Descriptive Statistics (Beta WML sorted)

\begin{tabular}{cccccc}
\hline \hline & P1 & P2 & P3 & P4 & P5 \\
excess return & 0.01 & 0.43 & 1.38 & 2.75 & 3.58 \\
& & & & & \\
standard deviation & 9.17 & 9.79 & 9.38 & 9.15 & 8.68 \\
Sharpe Ratio & 0.00 & 0.04 & 0.15 & 0.30 & 0.41
\end{tabular}

Notes: Table 8 provides annualized excess returns, the corresponding standard deviation and Sharpe ratio of currency portfolios sorted according to country $k$ currency excess return exposure to the winner-minus-loser factor obtained from the rolling-window regression

$$
\phi_{t}^{k}=\mu+\beta_{t}^{k, w m l} w m l_{t}^{F X}+\varepsilon_{t}^{k}
$$

with a time window of 36 months. The sample period runs from January 1971 to March 2008 and comprises 21 developed economies. Portfolio P1 contains the currency excess returns with lowest $\beta_{t}^{k, w m l}, \mathrm{P} 5$ contains the high $\beta_{t}^{k, w m l}$ currencies. 
Table 9: Cross-sectional performance of two-factor model (subsamples)

\begin{tabular}{|c|c|c|c|c|c|}
\hline \multicolumn{6}{|c|}{ Panel A: Jan 1971 - Dec 1989} \\
\hline & $b^{f x}$ & $b^{H L M}$ & J-test (p-value) & & \\
\hline GMM & $\begin{array}{l}1.81 \\
(0.61)\end{array}$ & $\begin{array}{l}4.72 \\
(1.19)\end{array}$ & 0.97 & & \\
\hline \multirow[t]{2}{*}{ FMB } & $\lambda^{f x}$ & $\lambda^{H L M}$ & $R^{2}$ & mspe & mape \\
\hline & $\begin{array}{c}1.63 \\
(0.82) \\
\end{array}$ & $\begin{array}{c}1.71 \\
(1.30) \\
\end{array}$ & 0.75 & 0.05 & 0.17 \\
\hline \multicolumn{6}{|c|}{ Panel B: Jan 1990 - Mar 2008} \\
\hline & $b^{f x}$ & $b^{H L M}$ & J-test (p-value) & & \\
\hline GMM & $\begin{array}{l}4.48 \\
(1.26)\end{array}$ & $\begin{array}{l}8.88 \\
(2.10)\end{array}$ & 0.93 & & \\
\hline \multirow[t]{2}{*}{ FMB } & $\lambda^{f x}$ & $\lambda^{H L M}$ & $R^{2}$ & mspe & mape \\
\hline & $\begin{array}{c}2.42 \\
(1.39)\end{array}$ & $\begin{array}{l}3.17 \\
(2.29)\end{array}$ & 0.84 & 0.07 & 0.23 \\
\hline
\end{tabular}

Notes: Table 9 reports the performance of the two-factor model in crosssectional asset pricing tests with regard to the 6-6 stock market momentum sorted currency portfolios described in table 1 for two subsample periods. Panel A provides the two stage GMM estimates as well as Fama-MacBeth risk price estimates for the sample period from January 1971 to December 1989, panel B presents the corresponding results for the sample period from January 1990 to March 2008. Further details are given in the notes of table 6 . 
Table 10: Macroeconomic risk factors and stock momentum based currency risk premia

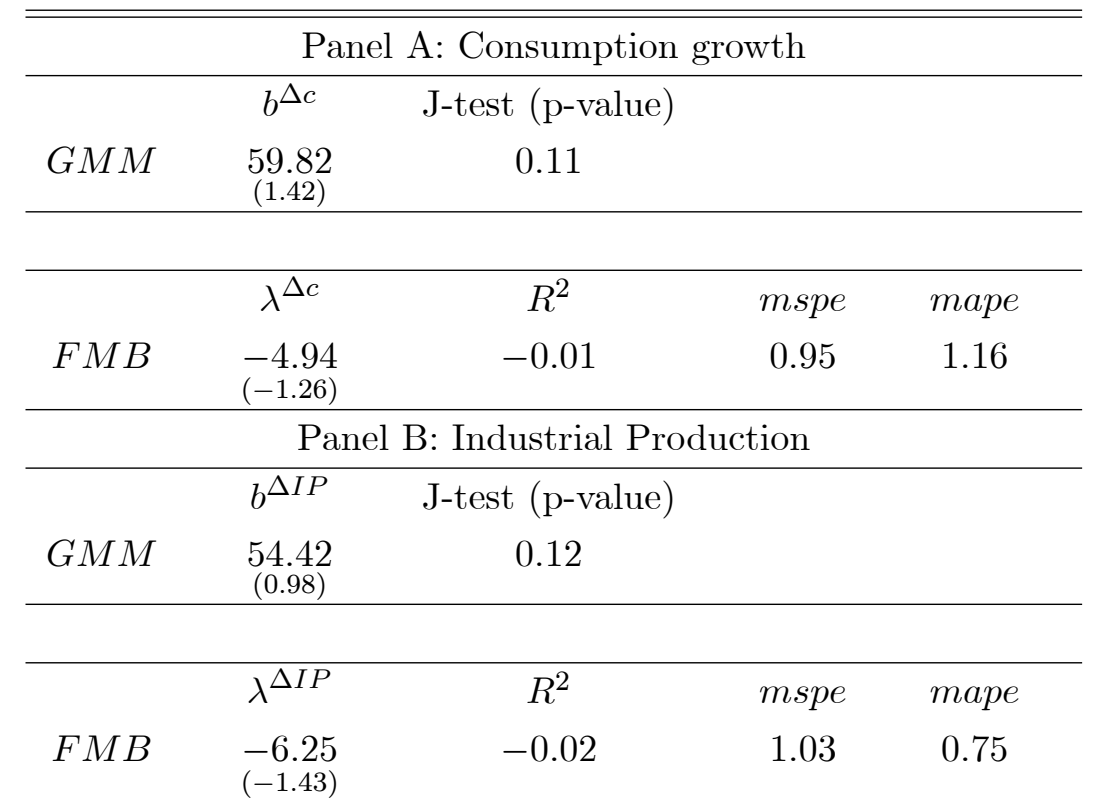

Notes: Table 10 reports the results when non-durable and services consumption growth (Panel A) and changes in U.S. industrial production (Panel B) are used to rationalize the cross-sectional variation of 6-6 stock market momentum sorted currency portfolios. The row 'GMM' provides the two stage GMM estimates of the factor loadings. I use the identity matrix as weighting matrix in the first stage and the optimal weighting matrix in the second stage. Newey-West (1987) corrected t-statistics appear below the estimates in parenthesis. The row 'FMB' presents estimates of risk prices obtained from Fama-MacBeth cross-sectional regressions where $R^{2}$, mean squared pricing error (mspe) and mean absolute pricing errors (mape) are in percentage points p.a. T-statistics in parenthesis are Shanken (1992) corrected. The sample period runs from January 1971 to March 2008 and comprises 21 developed economies. 
Table 11: Time series predictability of $w m l^{f x}$

\begin{tabular}{ccccccc}
\hline \hline & $\mathrm{h}=1$ & $\mathrm{~h}=2$ & $\mathrm{~h}=3$ & $\mathrm{~h}=6$ & $\mathrm{~h}=9$ & $\mathrm{~h}=12$ \\
\hline$\Delta i p$ & 0.06 & -0.17 & -0.62 & -1.27 & -1.53 & -1.34 \\
& $(0.29)$ & $(-0.45)$ & $(-1.29)$ & $(-1.53)$ & $(-1.65)$ & $(-1.36)$ \\
$R^{2}$ & 0.00 & 0.00 & 0.01 & 0.02 & 0.02 & 0.01 \\
\hline & & & & & & \\
\hline tspread & -0.00 & -0.04 & -0.06 & 0.27 & 1.50 & 3.23 \\
& $(-0.01)$ & $(-0.05)$ & $(-0.05)$ & $(0.12)$ & $(0.52)$ & $(0.88)$ \\
$R^{2}$ & 0.00 & 0.00 & 0.00 & 0.00 & 0.00 & 0.02 \\
\hline & & & & & & \\
\hline dspread & -0.26 & -0.18 & -0.11 & -0.85 & -1.72 & -1.74 \\
$R^{2}$ & $(-0.29)$ & $(-0.11)$ & $(-0.05)$ & $(-0.20)$ & $(-0.34)$ & $(-0.31)$ \\
& 0.00 & 0.00 & 0.00 & 0.00 & 0.00 & 0.00 \\
\hline & & & & & & \\
\hline vvix & 0.01 & -0.00 & -0.00 & -0.00 & -0.01 & -0.02 \\
$R^{2}$ & $(0.91)$ & $(-0.31)$ & $(-0.29)$ & $(-0.35)$ & $(-0.45)$ & $(-1.48)$ \\
& 0.00 & 0.00 & 0.00 & 0.00 & 0.00 & 0.00 \\
\hline & & & & & & \\
\hline ted & 0.97 & 1.45 & 1.24 & 0.73 & 4.87 & 8.76 \\
$R^{2}$ & $(0.61)$ & $(0.51)$ & $(0.29)$ & $(0.07)$ & $(0.31)$ & $(0.42)$ \\
& 0.00 & 0.00 & 0.00 & 0.00 & 0.00 & 0.00
\end{tabular}

Notes: This table provides estimates from the regression

$$
w m l_{t, t+h}^{f x}=\mu+\beta^{h} x_{t}+\varepsilon_{t, t+h}
$$

with $x_{t}$ one of the macroeconomic variables proposed by Chan, Roll and Ross (1986), namely changes in the U.S. industrial production index $(\Delta i p)$, the yield difference between a long-term government bond and the 3-month treasury bill (tspread), the yield difference between a Baa rated corporate bond and a long-term government bond (dspread) or the liquidity risk variables suggested by Brunnermeier, Nagel and Pedersen (2008): changes in the CBOE volatiliy index ( $\Delta v i x)$ and the yield difference between the eurodollar 3-month LIBOR and the 3-month treasury bill $(t e d)$. The forecast horizon, $\mathrm{h}$, is in months. The sample period runs from January 1971 to March 2008. Newey-West (1987) corrected t-statistics appear below the estimates in parenthesis. $R^{2}$ gives the measure of fit. 
Table 12: Risk prices conditional model

\begin{tabular}{|c|c|c|c|c|c|c|}
\hline$x$ & $\lambda^{f x}$ & $\lambda^{W M L}$ & $\overline{\lambda^{x} \bullet W M L}$ & $\bar{R}^{2}$ & mspe & mape \\
\hline$\Delta i p$ & $\begin{array}{l}1.99 \\
(1.50)\end{array}$ & $\begin{array}{l}2.36 \\
(2.48)\end{array}$ & $\begin{array}{l}0.02 \\
(0.67)\end{array}$ & 0.89 & 0.01 & 0.07 \\
\hline tspread & $\begin{array}{l}1.99 \\
(1.50)\end{array}$ & $\begin{array}{l}2.39 \\
(2.51)\end{array}$ & $\begin{array}{l}0.01 \\
(0.24)\end{array}$ & 0.85 & 0.03 & 0.14 \\
\hline dspread & $\begin{array}{l}1.99 \\
(1.50)\end{array}$ & $\begin{array}{l}2.36 \\
(2.47)\end{array}$ & $\begin{array}{l}0.01 \\
(0.83)\end{array}$ & 0.90 & 0.01 & 0.05 \\
\hline$\Delta v i x$ & $\begin{array}{l}2.42 \\
(1.37)\end{array}$ & $\begin{array}{l}3.05 \\
(2.18)\end{array}$ & $\begin{array}{l}0.07 \\
(0.11)\end{array}$ & 0.85 & 0.05 & 0.18 \\
\hline ted & $\begin{array}{l}1.99 \\
(1.50)\end{array}$ & $\begin{array}{l}2.38 \\
(2.50)\end{array}$ & $\begin{array}{l}-0.01 \\
(-0.48)\end{array}$ & 0.85 & 0.03 & 0.16 \\
\hline
\end{tabular}

Notes: Table 12 provides risk price estimates in percentage points p.a. from Fama-MacBeth regressions of 6-6 stock market momentum sorted currency portfolio excess returns on the two common factors and the winner-minus-loser factor interacted with a variable that could forecast currency risk premia.

1st stage: $\phi_{t+1}^{j}=\alpha+\beta^{r f x, j} r_{t+1}^{f x}+\beta^{w m l f x \cdot j} w m l_{t+1}^{f x}+\beta^{x, j} x_{t} \bullet w m l_{t+1}^{f x}+\varepsilon_{t+1}^{j}$

2nd stage: $\phi_{t}^{j}=\mu+\widehat{\beta}^{r f x, j} \lambda^{r f x}+\widehat{\beta}^{w m l f x \cdot j} \lambda^{w m l f x}+\widehat{\beta}^{x, j} \lambda^{x \bullet w m l f x}+v_{t}^{j}, \forall t$

with $x_{t}$ one of the macroeconomic variables proposed by Chan, Roll and Ross (1986), namely changes in the U.S. industrial production index $(\Delta i p)$, the yield difference between a long-term government bond and the 3-month treasury bill (tspread), the yield difference between a Baa rated corporate bond and a long-term government bond (tspread) or the crash and liquidity risk variables suggested by Brunnermeier, Nagel and Pedersen (2008): changes in the CBOE volatiliy index $(\Delta v i x)$ and the yield difference between the eurodollar 3-month LIBOR and the 3-month treasury bill (ted).T-statistics in parenthesis below the risk price estimates are Shanken (1992) corrected. $R^{2}$ is adjusted for the number of regressors. The columns mspe and mape give the mean squared as well as the mean absolute pricing errors of the model. The sample period runs from January 1971 to March 2008 for all specifications except for the use of $\Delta v i x$ for which data is only available from February 1990. 
Table 13: Stock Momentum based and HML interest rate factor

\begin{tabular}{cccccc}
\hline \hline \multicolumn{5}{c}{ Panel A: GMM (factor loadings) } \\
\hline$b^{f x}$ & $b^{W M L}$ & $b^{H M L}$ & J-test (p-value) \\
2.75 & 6.71 & 0.21 & 0.84 & \\
$(0.93)$ & $(2.31)$ & $(0.02)$ & \multicolumn{5}{c}{ Panel B: Fama-MacBeth risk prices } \\
\hline \multicolumn{5}{c}{${ }^{\text {Pan }}$} \\
\hline$\lambda^{f x}$ & $\lambda^{W M L}$ & $\lambda^{H M L}$ & $R^{2}$ & mape \\
1.99 & 2.39 & 0.12 & 0.85 & 0.03 & 0.15 \\
$(1.50)$ & $(2.51)$ & $(0.02)$ & & &
\end{tabular}

Notes: Table 13 reports the performance of two currency portfolio factors together with the high-minus-low interest rate factor, HML, from Lustig et al. (2008) as additional, macroeconomic factor when confronted with the 6-6 stock market momentum sorted currency portfolios described in table 1. Panel A provides the two stage GMM estimates of the factor loadings. I use the identity matrix as weighting matrix in the first stage and the optimal weighting matrix in the second stage. Newey-West (1987) corrected t-statistics appear below the estimates in parenthesis. Panel B presents estimates of risk prices, $R^{2}$, mean squared pricing error (mspe) and mean absolute pricing errors (mape) in percentage points p.a. T-statistics in parenthesis are Shanken (1992) corrected. The sample period runs from January 1971 to March 2008 and comprises 21 developed economies. 
Table 14: Average financial integration and risk sharing

\begin{tabular}{ccccc}
\hline \hline \multicolumn{5}{c}{ Panel A: Financial integration } \\
\hline P1 & P2 & P3 & P4 & P5 \\
0.97 & 1.11 & 1.13 & 1.14 & 1.18 \\
\multicolumn{5}{c}{ Panel B: Risk sharing } \\
\hline P1 & P2 & P3 & P4 & P5 \\
0.9519 & 0.9854 & 0.9943 & 0.9957 & 0.9961
\end{tabular}

Notes: Panel A of table 14 gives the average gross cross-border foreign equity holdings to GDP ratio of the countries included in the stock market momentum sorted currency portfolios. This foreign equity to GDP ratio can be interpreted as measure of financial integration (Lane and Milesi-Ferretti $(2001,2007)$ ). The sample period runs from January 1990 to December 2004.

Panel B of table 14 presents the risk sharing index of the (synthetic) country that backs the stock market momentum sorted currency portfolios vis-à-vis the United States. The risk sharing index is based on asset price data following Brandt et al. (2006). The sample period runs from January 1990 to March 2008. 
Table 15: Two-factor model (12-2 momentum)

\begin{tabular}{ccccc}
\hline \hline \multicolumn{5}{c}{ Panel A: GMM (factor loadings) } \\
\hline$b^{f x}$ & $b^{H L M}$ & J-test (p-value) \\
2.90 & 4.88 & 0.85 \\
$(1.26)$ & $(1.85)$ & \multicolumn{5}{c}{ Pan } \\
\hline \multicolumn{5}{c}{ Panel B: Fama-MacBeth risk prices } \\
\hline$\lambda^{f x}$ & $\lambda^{H L M}$ & $R^{2}$ & mspe & mape \\
1.96 & 2.12 & 0.88 & 0.06 & 0.23 \\
$(1.48)$ & $(1.98)$ & & &
\end{tabular}

Notes: Table 15 reports the performance of the two-factor model in crosssectional asset pricing tests with regard to currency portfolios sorted according to 12-2 stock market momentum as described in table 2. Panel A provides the two stage GMM estimates of the factor loadings. I use the identity matrix as weighting matrix in the first stage and the optimal weighting matrix in the second stage. Newey-West (1987) corrected t-statistics appear below the estimates in parenthesis. Panel B presents estimates of risk prices, $R^{2}$, mean squared pricing error (mspe) and mean absolute pricing errors (mape) in percentage points p.a. T-statistics in parenthesis are Shanken (1992) corrected. The sample period runs from January 1971 to March 2008 and comprises 21 developed economies 
Table 16: Two-factor model (emerging markets)

\begin{tabular}{ccccc}
\hline \hline \multicolumn{5}{c}{ Panel A: GMM (factor loadings) } \\
\hline$b^{f x}$ & $b^{W M L}$ & J-test (p-value) \\
17.79 & 1.26 & 0.19 \\
$(2.23)$ & $(0.40)$ & \multicolumn{5}{c}{ Panel B: } & \\
\hline \multicolumn{5}{c}{ Pama-MacBeth risk prices } \\
\hline$\lambda^{f x}$ & $\lambda^{W M L}$ & $R^{2}$ & mspe & mape \\
2.80 & 1.92 & -0.30 & 1.09 & 2.51 \\
$(3.02)$ & $(0.86)$ & & &
\end{tabular}

Notes: Table 16 reports the performance of the two-factor model in crosssectional asset pricing tests with regard to 6-6 stock market momentum sorted currency portfolios as described in table 3 for a sample of 24 emerging markets. Panel A provides the two stage GMM estimates of the factor loadings. I use the identity matrix as weighting matrix in the first stage and the optimal weighting matrix in the second stage. Newey-West (1987) corrected t-statistics appear below the estimates in parenthesis. Panel $\mathrm{B}$ presents estimates of risk prices, $R^{2}$, mean squared pricing error (mspe) and mean absolute pricing errors (mape) in percentage points p.a. T-statistics in parenthesis are Shanken (1992) corrected. The sample period runs from January 1989 to March 2008. 
Table 17: Two-factor model (long-term reversal)

\begin{tabular}{ccccc}
\hline \hline \multicolumn{5}{c}{ Panel A: GMM (factor loadings) } \\
\hline$b^{f x}$ & $b^{W M L}$ & J-test (p-value) \\
0.40 & 12.19 & 0.49 \\
$(0.17)$ & $(3.37)$ & \multicolumn{4}{c}{ mspe } & mape \\
\hline \multicolumn{5}{c}{ Panel B: Fama-MacBeth risk prices } \\
\hline$\lambda^{f x}$ & $\lambda^{W M L}$ & $R^{2}$ & 0.32 & 0.53 \\
1.42 & 4.31 & 0.86 & &
\end{tabular}

Notes: Table 17 reports the performance of the two-factor model in crosssectional asset pricing tests with regard to currency portfolios sorted according to long-term past stock market returns as described in table 4 for a sample of 21 developed economies. Panel A provides the two stage GMM estimates of the factor loadings. I use the identity matrix as weighting matrix in the first stage and the optimal weighting matrix in the second stage. Newey-West (1987) corrected t-statistics appear below the estimates in parenthesis. Panel B presents estimates of risk prices, $R^{2}$, mean squared pricing error (mspe) and mean absolute pricing errors (mape) in percentage points p.a. T-statistics in parenthesis are Shanken (1992) corrected. The sample period runs from January 1975 to March 2008. 
Table 18: Descriptive Statistics (demeaned momentum)

\begin{tabular}{cccccc}
\hline \hline & P1 & P2 & P3 & P4 & P5 \\
excess return & 0.93 & 1.63 & 1.68 & 3.12 & 2.71 \\
& & & & & \\
standard deviation & 8.65 & 9.01 & 8.84 & 8.77 & 8.87 \\
Sharpe Ratio & 0.11 & 0.18 & 0.19 & 0.36 & 0.31 \\
\hline
\end{tabular}

Notes: Table 18 provides annualized excess returns, the corresponding standard deviation and Sharpe ratio of currency portfolios sorted according to 6-6 stock market momentum when the raw stock market returns are demeaned in order to account for unconditional expected returns. Bulkley and Nawosah (2007) show that stock return momentum basically vanishes when adjusting raw returns by unconditional expected returns. The sample period runs from January 1971 to March 2008 and comprises 21 developed economies. Portfolio P1 contains the currencies from the lowest momentum stock return countries, P5 contains the high stock market momentum currencies. 
Table 19: Two-factor model based on momentum of demeaned returns

\begin{tabular}{ccccc}
\hline \hline \multicolumn{5}{c}{ Panel A: GMM (factor loadings) } \\
\hline$b^{f x}$ & $b^{H L M}$ & J-test (p-value) \\
2.97 & 5.18 & 0.42 & \\
$(1.30)$ & $(1.80)$ & \multicolumn{5}{c}{ mspe } & mape \\
\hline \multicolumn{5}{c}{ Panel B: Fama-MacBeth risk prices } \\
\hline$\lambda^{f x}$ & $\lambda^{H L M}$ & $R^{2}$ & 0.27 & 0.41 \\
2.01 & 1.92 & 0.58 & & \\
$(1.51)$ & $(2.00)$ & &
\end{tabular}

Notes: Table 19 reports the performance of the two-factor model in crosssectional asset pricing tests with regard to the currency portfolios formed according to momentum in (demeaned) stock market returns thus taking account of Bulkley and Nawosah (2007) who show that stock return momentum basically vanishes when adjusting raw returns by unconditional expected returns. Panel A provides the two stage GMM estimates of the factor loadings. I use the identity matrix as weighting matrix in the first stage and the optimal weighting matrix in the second stage. Newey-West (1987) corrected t-statistics appear below the estimates in parenthesis. Panel B presents estimates of risk prices, $R^{2}$, mean squared pricing error (mspe) and mean absolute pricing errors (mape) in percentage points p.a. Tstatistics in parenthesis are Shanken (1992) corrected. The sample period runs from January 1971 to March 2008 and comprises 21 developed economies 
Table 20: Currency portfolio excess returns (international)

\begin{tabular}{lccccc}
\hline \hline & \multicolumn{6}{c}{ Germany } \\
\hline & P1 & P2 & P3 & P4 & P5 \\
excess return & -2.12 & -0.99 & -1.17 & 0.13 & 0.05 \\
\hline \multicolumn{7}{c}{ Japan } \\
\hline excess return & P1 & P2 & P3 & P4 & P5 \\
\hline & -1.02 & -0.24 & -0.88 & 0.67 & 0.85 \\
\hline \multicolumn{7}{c}{ United Kingdom } \\
excess return & P1 & P2 & P3 & P4 & P5 \\
& 1.12 & 1.84 & 2.11 & 3.02 & 3.26
\end{tabular}

Notes: Table 20 provides annualized excess returns on 6-6 stock market momentum sorted currency portfolios formed from the perspective of a German, Japanese and British investor. The sample period runs from January 1971 to March 2008 and comprises 21 developed economies. Portfolio P1 contains the currencies from the lowest momentum stock return countries, P5 contains the high stock market momentum currencies. 
Table 21: Cross-sectional performance of two-factor model (international)

\begin{tabular}{|c|c|c|c|c|c|}
\hline \multicolumn{6}{|c|}{ Panel A: Germany } \\
\hline & $b^{f x}$ & $b^{H L M}$ & J-test (p-value) & & \\
\hline GMM & $\begin{array}{l}-3.83 \\
(-1.09)\end{array}$ & $\begin{array}{l}6.04 \\
(1.99)\end{array}$ & 0.68 & & \\
\hline \multirow[t]{2}{*}{ FMB } & $\lambda^{f x}$ & $\lambda^{H L M}$ & $R^{2}$ & mspe & mape \\
\hline & $\begin{array}{l}-0.84 \\
(-1.07)\end{array}$ & $\begin{array}{l}2.22 \\
(2.27)\end{array}$ & 0.76 & 0.16 & 0.31 \\
\hline \multicolumn{6}{|c|}{ Panel B: Japan } \\
\hline & $b^{f x}$ & $b^{H L M}$ & J-test (p-value) & & \\
\hline GMM & $\begin{array}{l}0.06 \\
(0.03)\end{array}$ & $\begin{array}{l}5.35 \\
(1.98)\end{array}$ & 0.62 & & \\
\hline \multirow[t]{2}{*}{ FMB } & $\lambda^{f x}$ & $\lambda^{H L M}$ & $R^{2}$ & mspe & mape \\
\hline & $\begin{array}{l}-0.12 \\
(-0.08)\end{array}$ & $\begin{array}{l}1.99 \\
(2.02) \\
\end{array}$ & 0.71 & 0.17 & 0.31 \\
\hline \multicolumn{6}{|c|}{ Panel C: United Kingdom } \\
\hline & $b^{f x}$ & $b^{H L M}$ & J-test (p-value) & & \\
\hline GMM & $\begin{array}{l}4.21 \\
(1.71)\end{array}$ & $\begin{array}{l}5.57 \\
(1.91)\end{array}$ & 0.89 & & \\
\hline \multirow[t]{2}{*}{ FMB } & $\lambda^{f x}$ & $\lambda^{H L M}$ & $R^{2}$ & mspe & mape \\
\hline & $\underset{(1.86)}{2.27}$ & $\begin{array}{l}2.27 \\
(2.27)\end{array}$ & 0.84 & 0.06 & 0.19 \\
\hline
\end{tabular}

Notes: Table 21 reports the performance of the two-factor model in crosssectional asset pricing tests with regard to the 6-6 stock market momentum sorted currency portfolios from the perspective of a German (panel A), Japanese (panel B) and British (panel C) investor. Further details of the two-factor model are described in table 6. The sample period runs from January 1971 to March 2008. 


\section{Figures}

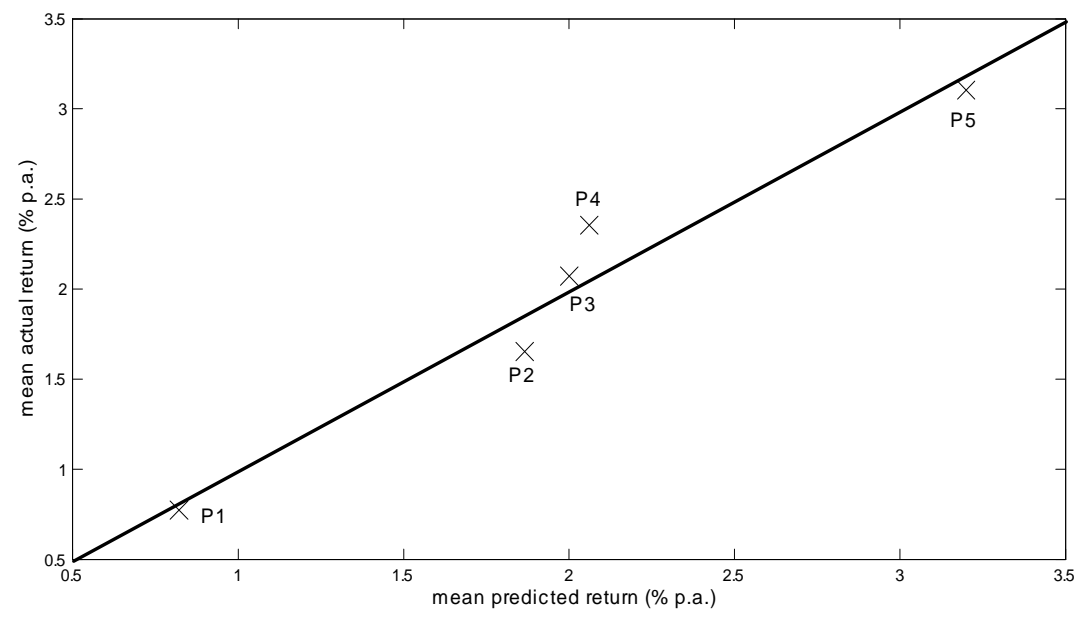

Figure 1: Fit of two-factor model based on 6-6 stock market momentum sorted currency portfolios. 


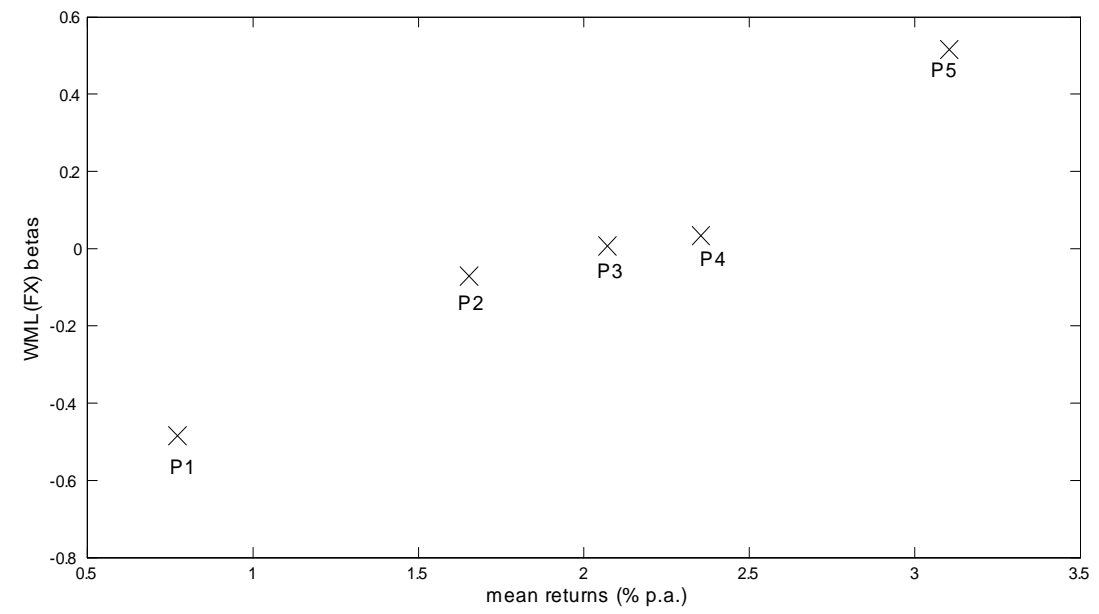

Figure 2: Average currency portfolio excess returns (6-6 stock market momentum sorted) vs. exposure to winner-minus-loser factor 


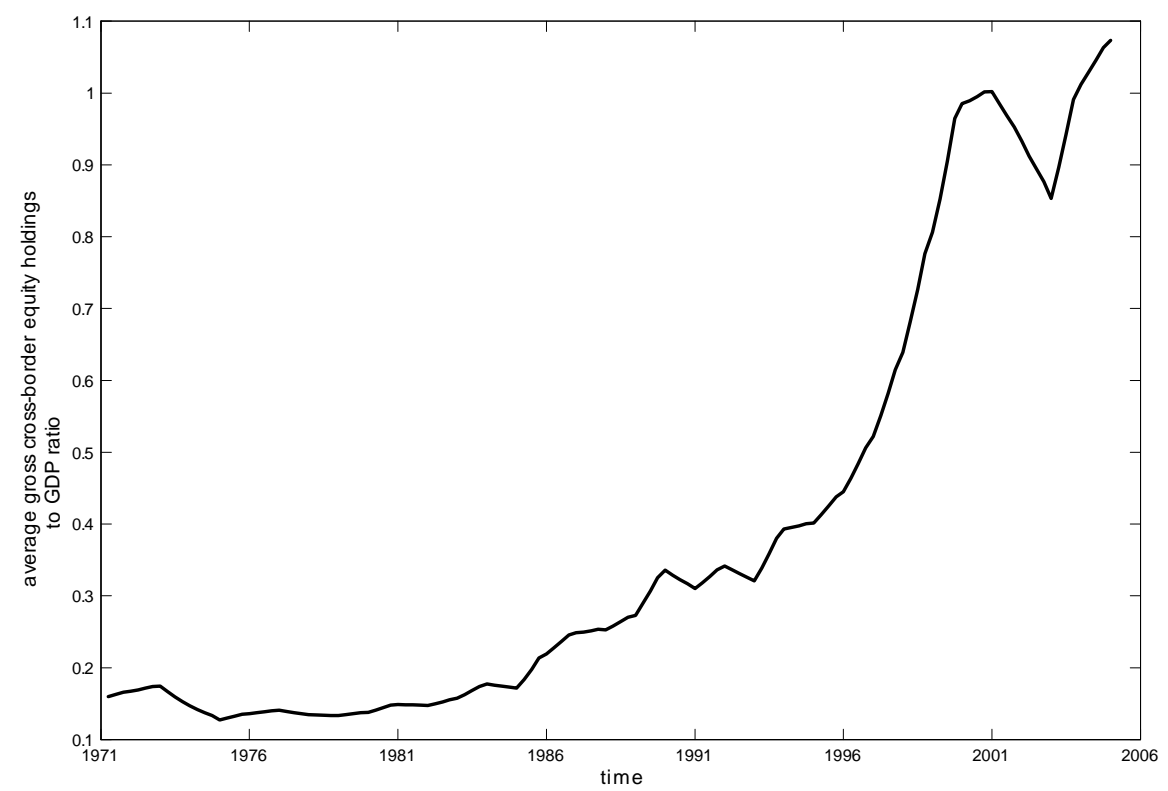

Figure 3: Average gross cross-border equity holdings to GDP ratio of the 21 developed economies under study. The sample period runs from 1970 to 2004 . 


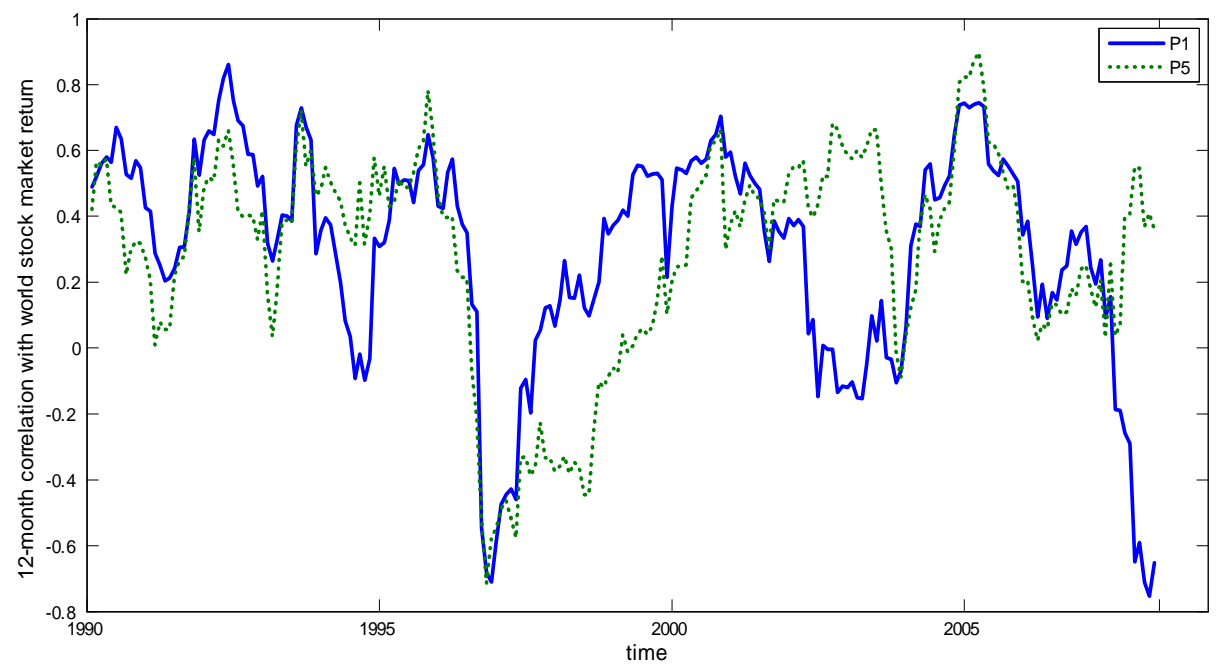

Figure 4: 12-month correlation of high and low stock market momentum based currency portfolio excess returns with world stock market return. P5 contains the high stock market momentum, P1 the low stock market momentum currencies. 